\title{
Development of Scale to Measure Attitude of Farmers towards Plant Protection Measures
}

\author{
Kundan Kumar $^{1 *}$ and Wapangtoshi Longkumer ${ }^{2}$ \\ ${ }^{1}$ (Agril. Extension), Krishi Vigyan Kendra, Nagaland University, \\ Lumami-798627 (Nagaland), India \\ 2 (Plant Protection), Krishi Vigyan Kendra, Nagaland University, \\ Lumami-798627 (Nagaland), India
}

*Corresponding author

\section{A B S T R A C T}

\section{Keywords}

Attitude, Farmers,

Plant protection

measures, Scale

Article Info

Accepted:

17 June 2019

Available Online:

10 July 2019
Plant protection measures is the essential component of farming which play important role in saving the crops from diseases and insect-pest, therefore agricultural extension have a big role to play in finding the solution and providing it to the end users to get the technology disseminated at the earliest possible time with appropriate application, for which a scale was developed to measure the attitude of farmer towards plant protection measures based on Likert's techniques. A total of 50 statements were prepared, and these statements were administered to the 30 number of farmer from non-sample area from two villages each covering of 15 farmers. A final list of 11 Statements were selected based on the ' $t$ ' values $(\geq 1.745)$ obtained from the item analysis.

\section{Introduction}

The plant protection measures are the decision taken by the farmers which would benefit from a better understanding of the functioning and dynamics of ecosystems, and the role of pests as an integral part of agro-biodiversity.

The extension personal, who are often targets of complex information regarding crop pests, would also benefit from a better understanding of the real impact of pests and diseases in cropping ecosystems. The attitude of farmers decides for the application of appropriate technology,

Therefore it is very much necessary to develop an attitudinal scale, which will help in deciding upon the technology to be disseminated at the farmers' field keeping in view of their suitability and also assessing the degree of affect that an individual farmer may associate with some psychological objects, idea, institution or a phenomenon. 


\section{Materials and Methods}

The method of summated rating suggested by Likert (1932) was followed in the development of scale to measure the attitude of farmer towards the plant protection measures. A total of 50 statements, expressing the attitude of farmers towards the plant protection measures were collected based on the applicability of statements to study area. For this study 30 farmers were selected from two non-sample villages each covering of 15 farmers. The responses were obtained on a five point continuum viz., Strongly Agree(SA), Agree(A), Undecided(UD), Disagree(DA) and Strongly Disagree(SDA) with a score of 5, 4, 3, 2, and 1 respectively for the positive statement and for the negative statement reverse scoring was adopted.

The respondents were arranged in descending order based on the obtained score for each and every statement. After that criterion group was selected, i.e. 25 per cent of the respondents having the high score and 25 per cent of the respondents having the low score were taken. The ' $t$ ' value for each statement was calculated by using the following formula given by Edwards(1969).

$$
t=\frac{\bar{X}_{H}-\bar{X}_{L}}{\sqrt{\frac{\sum\left(X_{H}-\bar{X}_{H}\right)^{2}+\sum\left(X_{L}-\bar{X}_{U}\right)^{2}}{n(n-1)}}}
$$

Where,

$$
\sum\left(X_{H}-\bar{X}_{H}\right)^{2}=\sum X_{H}^{2}-\frac{\left(\sum_{H}\right)^{2}}{n} ; \sum\left(X_{L}-\bar{X}_{L}\right)^{2}=\sum X_{L}^{2}-\frac{\left(\sum g_{L}\right)^{2}}{n}
$$

$\overline{\mathrm{X}} \mathrm{H}$ - The mean score on given statement of the high group

$\overline{\mathrm{X}} \mathrm{L}$ - The mean score on given statement of the low group $\sum \mathrm{X}_{\mathrm{H}^{-}}$Summation of score on a given statement for high group

$\sum \mathrm{X}_{\mathrm{H}}{ }^{2}$ - Sum of squares of the individual score on a given statement for high group

$\sum \mathrm{X}_{\mathrm{L}^{-}}$Summation of score on a given statement for low group

$\sum \mathrm{X}_{\mathrm{L}}{ }^{2}$ - Sum of squares of the individual score on a given statement for Low group

$\mathrm{n}$ - Number of respondents in each group

$\sum$ - Summation

The obtained score of each individual for every statement has been calculated which ranges from 168 to 204 and then ' $t$ ' value were calculated using the above mentioned formula given by Edwards (1969).

The calculated ' $t$ ' value ranges from 0.00 to 3.210 and the statement with ' $t$ ' values of 1.745 and above (Table 1) were considered for the final inclusion (Table 2).

The final scale to measure the attitude of farmers' towards plant protection measures has been developed, where 11 statements were included and some of the statement are, plant protection measures should be used to increase the yield, plant protection chemicals have a wide variety of bad impact on the environment, application of insecticides and pesticides kills many insects including beneficial, Farmers get opportunity to use knowledge, attitude and skill when they practice the traditional methods of plant protection and so on. And these 11 statements represent the various aspects about plant protection measures.

Pesticide kills pests but also pests' natural enemies, and their overuse can harm farmers, consumers and the environment, 
Table.1 The statements of item analysis by farmers of non-sample area

\begin{tabular}{|c|c|c|}
\hline Sl. No & Statement & 't' Values \\
\hline 1. & I feel that plant protection measures should be used to increase the yield & $-2.645^{*}$ \\
\hline 2. & I prefer to use plant protection measures without chemicals(Insecticides/Pesticides) & 0.000 \\
\hline 3. & $\begin{array}{l}\text { It is obvious to get less yield when we use plant protection measures in organic } \\
\text { mode }\end{array}$ & -0.824 \\
\hline 4. & $\begin{array}{l}\text { Adoption of plant protection brings more prestige and social status as the fellow } \\
\text { farmers think that I am knowledgeable }\end{array}$ & 1.047 \\
\hline 5. & Plant protection requires technical knowledge which I am aware off & 1.255 \\
\hline 6. & Plant protection chemicals have a wide variety of bad impact on the environment & $2.138 *$ \\
\hline 7. & $\begin{array}{l}\text { I am the right person to convince the fellow farmers to use insecticides and } \\
\text { pesticides as a plant protection measures if there is severe damage }\end{array}$ & 0.715 \\
\hline 8. & IPM helps to retain level of farm organisms and birds & 0.385 \\
\hline 9. & $\begin{array}{l}\text { An innovative farmers who is using the plant protection measures in judicious way } \\
\text { should be given media publicity }\end{array}$ & 0.797 \\
\hline 10. & $\begin{array}{l}\text { Analysis and evaluation of environmental impact of plant protection measures gives } \\
\text { the idea to use the appropriate methods which are comparatively environmental } \\
\text { friendly }\end{array}$ & 1.571 \\
\hline 11. & $\begin{array}{l}\text { Environmentally oriented plant protection strategies are characterised by targeted } \\
\text { fostering and use of eco-system specific limiting factors }\end{array}$ & 0.277 \\
\hline 12. & Application of insecticides and pesticides kills many insects including beneficial & $2.443^{*}$ \\
\hline 13. & $\begin{array}{l}\text { I prefer tradition methods of insect-pest and disease control rather than chemical } \\
\text { application }\end{array}$ & 0.782 \\
\hline 14. & $\begin{array}{l}\text { I am very much careful in using chemicals method of plant protection measures } \\
\text { because of its poisonous in nature }\end{array}$ & -0.541 \\
\hline 15. & $\begin{array}{l}\text { I find problem in sourcing and purchasing the equipments and tools used for } \\
\text { spraying of plant protection chemicals }\end{array}$ & -1.033 \\
\hline 16. & $\begin{array}{l}\text { I feel that govt. Should promote plant protection technology on farmers field with } \\
\text { providing assistance to the farmers }\end{array}$ & 0.191 \\
\hline 17. & Adoption of plant protection is boon to the farmers & 0.305 \\
\hline 18. & $\begin{array}{l}\text { I believe that SHGs and cooperative societies will be much helpful in making } \\
\text { available the plant protection chemicals at village level }\end{array}$ & -0.353 \\
\hline 19. & $\begin{array}{l}\text { Mixing of proper dosages of plant protection chemicals with right quantity is very } \\
\text { laborious and difficult task }\end{array}$ & 1.141 \\
\hline 20. & Farmers need training for adoption of plant protection measures in appropriate way & 0.344 \\
\hline 21. & $\begin{array}{l}\text { My farm location is not at all suitable for adoption of chemical methods of plant } \\
\text { protection as the neighbouring area are being cultivated through organic methods }\end{array}$ & $2.017 *$ \\
\hline 22. & $\begin{array}{l}\text { Farmers get opportunity to use knowledge, attitude and skill when they practice the } \\
\text { traditional methods of plant protection }\end{array}$ & $2.593 *$ \\
\hline 23. & $\begin{array}{l}\text { I prefer not to use chemical method of plant protection as there is less demand for } \\
\text { inorganic product }\end{array}$ & 0.551 \\
\hline 24. & $\begin{array}{l}\text { I will not hesitate to use even more than the recommended quantity of chemicals as } \\
\text { a plant protection for getting higher income }\end{array}$ & 1.232 \\
\hline 25. & $\begin{array}{l}\text { I always prefer to use chemicals as a plant protection only after consultation with } \\
\text { agricultural experts }\end{array}$ & $1.870^{*}$ \\
\hline
\end{tabular}




\begin{tabular}{|c|c|c|}
\hline 26. & $\begin{array}{l}\text { Purchasing of equipments and tools is not that much difficult from financial point of } \\
\text { view but it is difficult to get to it repaired }\end{array}$ & 0.966 \\
\hline 27. & $\begin{array}{l}\text { I prefer to use locally adaptable insect- pest and disease resistant varieties instead of } \\
\text { using chemicals as a plant protection measures }\end{array}$ & 1.411 \\
\hline 28. & $\begin{array}{l}\text { I am very much concern for production and profit that's why I will use chemical } \\
\text { methods of plant protection to maximise my income }\end{array}$ & -0.651 \\
\hline 29. & $\begin{array}{l}\text { The food problem of the country can only be solved by using plant protection } \\
\text { chemicals for controlling the insect-pest and diseases }\end{array}$ & $3.210^{*}$ \\
\hline 30. & $\begin{array}{l}\text { Chemicals methods of plant protection measures are economical as it requires more } \\
\text { time and labour }\end{array}$ & $2.346^{*}$ \\
\hline 31. & Use of chemical method of plant protection leads to health hazards & -0.403 \\
\hline 32. & $\begin{array}{l}\text { Adoption of scientific methods of plant protection measures will not be able to fetch } \\
\text { higher income as it requires more investment }\end{array}$ & 0.977 \\
\hline 33. & $\begin{array}{l}\text { I feel that young farmers will take up the plant protection measures since it is new } \\
\text { technology and also requires motivation }\end{array}$ & 0.475 \\
\hline 34. & $\begin{array}{l}\text { Chemicals of good brand to control insect-pest and diseases is not easily available } \\
\text { in the market }\end{array}$ & 1.278 \\
\hline 35. & $\begin{array}{l}\text { I always take advice/suggestion from input dealer because agricultural experts may } \\
\text { not be available all the time }\end{array}$ & $2.083 *$ \\
\hline 36. & $\begin{array}{l}\text { Plant protection chemicals should be banned because it destroys the crops and also } \\
\text { affect the environment }\end{array}$ & 1.527 \\
\hline 37. & $\begin{array}{l}\text { There are more challenges in doing adopting scientific way of plant protection } \\
\text { measures }\end{array}$ & 1.141 \\
\hline 38. & I believe that biological methods of plant protection is kinder to environment & -1.111 \\
\hline 39. & I feel it is better to uproot infested plant instead of applying chemical & 0.195 \\
\hline 40. & I need to employ more labour in adopting scientific methods of plant protection & 1.722 \\
\hline 41. & $\begin{array}{l}\text { It is very difficult to get genuine product of plant protection as we get adulterated } \\
\text { product in the market }\end{array}$ & 0.385 \\
\hline 42. & Application of plant protection chemicals at right time brings more monetary return & 0.780 \\
\hline 43. & I feel that plant protection practices are suitable only for the big farmers & $1.861 *$ \\
\hline 44. & $\begin{array}{l}\text { Result demonstration of various type of plant protection measures will bring more } \\
\text { satisfaction since it follows the principle of "learning by doing" }\end{array}$ & 1.697 \\
\hline 45. & My farm will be more sustainable through organic methods of plant protection & 0.523 \\
\hline 46. & $\begin{array}{l}\text { If I think of animal welfare then I cannot adopt the chemical method of plant } \\
\text { protection }\end{array}$ & -0.475 \\
\hline 47. & $\begin{array}{l}\text { Our indigenous technical knowledge is better to control all type of insect-pest } \\
\text { infestation and diseases outbreak }\end{array}$ & 1.080 \\
\hline 48. & $\begin{array}{l}\text { I feel that nature of farming practices we do has no role in ecological } \\
\text { problem/environmental pollution }\end{array}$ & 1.716 \\
\hline 49. & $\begin{array}{l}\text { I would like to adopt chemical methods of plant protection measures even if we get } \\
\text { less price for the product }\end{array}$ & $1.783^{*}$ \\
\hline 50. & $\begin{array}{l}\text { Mechanical control of insect-pest and diseases is very laborious and difficult, that's } \\
\text { why it is essential to use plant protection chemicals }\end{array}$ & 1.326 \\
\hline
\end{tabular}


Table.2 Final scale developed to measure the attitude of farmers' towards Plant Protection Measures

\begin{tabular}{|c|c|c|}
\hline Sl. No & Statement & 't' Values \\
\hline 1. & I feel that plant protection measures should be used to increase the yield & $-2.645^{*}$ \\
\hline 2. & Plant protection chemicals have a wide variety of bad impact on the environment & $2.138^{*}$ \\
\hline 3. & Application of insecticides and pesticides kills many insects including beneficial & $2.443 *$ \\
\hline 4. & $\begin{array}{l}\text { My farm location is not at all suitable for adoption of chemical methods of plant } \\
\text { protection as the neighbouring area are being cultivated through organic methods }\end{array}$ & $2.017 *$ \\
\hline 5. & $\begin{array}{l}\text { Farmers get opportunity to use knowledge, attitude and skill when they practice } \\
\text { the traditional methods of plant protection }\end{array}$ & $2.593^{*}$ \\
\hline 6. & $\begin{array}{l}\text { I always prefer to use chemicals as a plant protection only after consultation with } \\
\text { agricultural experts }\end{array}$ & $1.870 *$ \\
\hline 7. & $\begin{array}{l}\text { The food problem of the country can only be solved by using plant protection } \\
\text { chemicals for controlling the insect-pest and diseases }\end{array}$ & $3.210^{*}$ \\
\hline 8. & $\begin{array}{l}\text { Chemicals methods of plant protection measures are economical as it requires } \\
\text { more time and labour }\end{array}$ & $2.346^{*}$ \\
\hline 9. & $\begin{array}{l}\text { I always take advice/suggestion from input dealer because agricultural experts may } \\
\text { not be available all the time }\end{array}$ & $2.083^{*}$ \\
\hline 10. & I feel that plant protection practices are suitable only for the big farmers & $1.861^{*}$ \\
\hline 11. & $\begin{array}{l}\text { I would like to adopt chemical methods of plant protection measures even if we get } \\
\text { less price for the product }\end{array}$ & $1.783^{*}$ \\
\hline
\end{tabular}

Therefore there is need to develop a healthy agro- ecosystem on the basis of the farmers attitude which will manage the farming system in very appropriate and efficient way, because pest management decision taken by each farmer are based on his or her individual objectives and experiences, therefore it is very much necessary to know the attitude of farmers, and for the same purpose a scale has been developed comprising of 11 statements which can be used to measure the attitude of farmers towards plant protection measures beyond the study area.

\section{References}

Edwards, A. L. (1969) Techniques of attitude scale construction, Vakils. Feffer and Simons Pvt. Ltd., Bombay

FAO (2011) "Save and Grow". A policymaker's guide to the sustainable intensification of small holder crop production. $65-76$

Likert, R. (1932) A technique for the measurement of attitudes. Arch. Psychology, 140, 44-53

\section{How to cite this article:}

Kundan Kumar and Wapangtoshi Longkumer. 2019. Development of Scale to Measure Attitude of Farmers towards Plant Protection Measures. Int.J.Curr.Microbiol.App.Sci. 8(07): 2229-2233. doi: https://doi.org/10.20546/ijcmas.2019.807.271 